\title{
TANGGUNG JAWAB MASKAPAI PENERBANGAN SEBAGAI PENYEDIA JASA PENERBANGAN KEPADA PENUMPANG AKIBAT KETERLAMBATAN PENERBANGAN
}

\author{
Oleh: Baiq Setiani \\ Fakultas Hukum Universitas Muhammadiyah Tanggerang \\ Pemerhati Penerbangan dan Dosen Hukum Udara \\ E-mail: baiqsetiani@yahoo.com
}

\begin{abstract}
The background of this research is the increasing frequency of passengers or users of air transport services in Indonesia who complained about the airline services, especially flight delays problems in the implementation of air transport services. Thus, it is important to reveal how the implementation of the airline responsibility as a flight services provider to the passengers in case of flight delays according to the legislation that applies. The method used is a normative juridical research. Based on this research, the form of airlines responsibilities applied the concept of legal presumption of innocence responsibility. The legal protection to passengers as a result of delays can be proven with air tickets. A suggestion in this study is the government should provide clear and assertive provisions on sanctions against the airlines if it does not provide compensation due to the delays.
\end{abstract}

Keywords: Responsibility of Airlines, Flight Services, Flight Delays

\section{A. LATAR BELAKANG}

Transportasi udara adalah alat transportasi yang relatif lebih muda dibandingkan dengan transportasi darat dan laut, sehingga sering dijuluki sebagai the most regulated transportation yang diatur oleh berbagai ketentuan nasional (termasuk hu-kum udara) yang diserasikan dengan ketentuan-ketentuan internasional (Baiq Setiani, 2015: 7).

Salah satu tujuan diselenggarakannya penerbangan adalah mewujudkan penyelenggaraan penerbangan yang aman (safety), tertib dan teratur (regularity), nyaman (comfortable), dan ekonomis (economy for company) (Nasution, 2007: 202204). Berawal dari tujuan tersebut terlihat dengan jelas bahwa sangat bertentangan dengan adanya peristiwa keterlambatan serta pembatalan penerbangan yang mencerminkan kurang disiplinnya pihak dari pelaku usaha transportasi.

Terselenggaranya suatu pengangkutan udara dalam kegiatan penerbangan komersil tidak akan berarti apa-apa tanpa adanya penumpang. Pada industri penerbangan, penumpang merupakan salah satu aset penting yang patut diperhitungkan 
bagi maskapai penerbangan untuk mencapai keuntungan. Oleh karena itu yang meng-gunakan jasa penerbangan perlu dilindungi haknya terutama hak ganti rugi apabila penumpang mengalami kecelakaan (yang menyebabkan kematian, lukaluka, atau cacat tetap), kerusakan atau kehilangan bagasi, dan keterlambatan (Pasal 25 ayat (1) Ordonansi Pengangkutan Udara) (Annalisa Yahanan et. al., 2009: 9). Jika penumpang merasa kuantitas atau kualitas barang atau jasa yang dikonsumsinya tidak sesuai dengan nilai tukar yang diberikannya, ia berhak mendapatkan ganti kerugian yang pantas (Shidarta, 2004: 28-29). Berkaitan dengan itu sebagai salah satu ciri pelayanan umum adalah pemberi pelayanan bertanggung jawab dalam arti liability dalam hal penerima layanan mengalami kerugian akibat layanan yang diberikan (K. Martono, 2009: 15).

Terkait dengan keterlambatan penerbangan, Pasal 1 angka 30 Undang-Undang No. 1 Tahun 2009 Tentang Penerbangan (selanjutnya disingkat UndangUndang Penerbangan) menjelaskan definisi keterlambatan sebagai "terjadinya perbedaan waktu antara waktu keberangkatan atau kedatangan yang dijadwalkan dengan reali-sasi waktu keberangkatan atau kedatangan".

Kenyataannya, transportasi udara tidak selamanya mendatangkan berbagai keuntungan bagi masyarakat terutama yang sangat penting adalah waktu. Transportasi udara memang dapat dengan cepat menghubungkan satu tujuan ke tujuan lainnya, namun di luar itu sering kali transportasi udara ini menimbulkan kerugian bagi penumpang, di mana maskapai terkadang tidak memenuhi apa yang sudah menjadi kewajibannya atau dengan kata lain wanprestasi.

Apabila penumpang yang menggunakan jasa penerbangan berakibat terjadinya pelanggaran hak-hak penumpang yang menimbulkan kerugian, maka pengangkut bertanggung jawab seperti yang diamanatkan oleh Undang-Undang Penerbangan. Tanggung jawab dimulai sebelum masa penerbangan (pre-flight service), pada saat penerbangan (in-flight service), dan setelah penerbangan (postflight service) (Su-harto dan Eko, 2009: 78). Kerugian sebelum masa penerbangan misalnya berkaitan dengan pembelian tiket, penyerahan bagasi, penempatan bagasi pada rute yang salah atau terjadi keterlambatan. Kerugian pada saat penerbangan misalnya tidak men-dapatkan pelayanan yang baik atau rasa aman untuk sampai di tujuan dengan sela-mat. Sedangkan kerugian setelah penerbangan, antara lain sampai di tujuan terlam-bat, bagasi hilang atau rusak.

Keterlambatan penerbangan yang dilakukan oleh pihak penyedia jasa penerbangan merupakan suatu pelanggaran, karena tidak terlaksananya suatu perjanjian pengangkutan dengan baik sesuai dengan yang telah disepakati sebelumnya. Pelanggaran atau tidak dilaksanakannya suatu perjanjian pengangkutan dapat timbul dalam hal sebagai berikut (E. Saefullah, 1989: 111):

1. Adanya penolakan secara tidak sah oleh pengangkut untuk melaksanakan perjajian pengangkutan.

2. Hanya sebagian dari pengangkutan itu yang dilaksanakan.

3. Adanya keterlambatan di pihak pengangkut dengan akibat bahwa sasaran dari pelaksanaan usaha tersebut menjadi terhalang atau tidak 
dapat dilaksanakan sesuai dengan yang seharusnya dan para penumpang di-benarkan menyatakan bahwa perjanjian tersebut batal.

Kerugian yang dialami oleh penumpang tidak hanya kerugian materil melain-kan juga kerugian immateril. Tidak mudah memang menuntut tanggung gugat sebuah maskapai penerbangan, namun yang terpenting adalah bagaimana peran pemerintah dalam membentuk suatu aturan untuk menentukan tanggung gugat para pihak khu-susnya pada pihak pengangkut jika dalam perusahaan penerbangan ada permasala-han.

Fokus penelitian ini adalah menyangkut keterlambatan penerbangan, ditinjau dari Undang-Undang Penerbangan dan Peraturan Menteri Perhubungan (PM) 77 Tahun 2011. Bertitik tolak dari uraian pada pendahuluan, maka terbentuk 2 rumusan masalah yaitu:

1. Bagaimana bentuk tanggung jawab maskapai penerbangan terhadap pe-numpang apabila terjadi keterlambatan penerbangan?

2. Bagaimana perlindungan hukum terhadap penumpang sebagai konsumen yang dirugikan akibat keterlambatan penerbangan?

Penelitian ini bertujuan untuk mengetahui dan menganalisis bagaimana bentuk tanggung jawab maskapai penerbangan terhadap penumpang apabila terjadi keterlambatan penerbangan serta dalam rangka untuk mengetahui dan menganalisa apa saja perlindungan hukum terhadap penumpang sebagai konsumen yang dirugikan akibat keterlambatan penerbangan menurut peraturan perundang-undangan yang berlaku.

\section{B. METODE PENELITIAN}

Jenis penelitian yang digunakan adalah penelitian yuridis normatif yang menekankan pada penelitian pustaka yang didukung oleh penelitian lapangan. Analisis dilakukan terhadap peraturan perundang-undangan yang mengatur tentang isu hukum yang sedang diangkat yaitu Undang-Undang Penerbangan dan PM 77 Tahun 2011. Tidak hanya itu saja, analisis yang digunakan tidak menutup pada berbagai sumber lain di mana memberikan celah untuk dapat dilakukannya analisis oleh penulis.

Tipe penelitian yang digunakan adalah pendekatan undang-undang (statute approach) dengan menganalisa berbagai regulasi dan peraturan perundang-undangan, dan pendekatan konseptual (conceptual approach) yang dilakukan dengan ber-pangkal pada pandangan-pandangan dan doktrin terkait dengan isu hukum yang se-dang diangkat.

Keaslian penelitian dimaksudkan bahwa masalah yang hendak diteliti belum pernah dipecahkan oleh peneliti terdahulu. Sepengetahuan penulis, penelitian tentang "Tanggung Jawab Maskapai Penerbangan Sebagai Penyedia Jasa Penerbangan Kepada Penumpang Terhadap Akibat Keterlambatan Penerbangan" belum dilakukan oleh banyak peneliti. Terkait persamaan dengan penelitian yang dilakukan oleh E. Saefullah Wiradipradja, penulis menemukan banyak perbedaan 
terkait penelitian ter-sebut, salah satunya dilihat dari judul penelitian beliau "Tanggung Jawab Perusahaan Penerbangan Terhadap Penumpang Menurut Hukum Udara Indonesia".

\section{PEMBAHASAN}

Berkenaan dengan pengangkutan udara, hal yang sudah sering kali terjadi adalah tentang keterlambatan jadwal keberangkatan pesawat udara di mana terjadi perbedaan waktu keberangkatan yang tercantum di dalam tiket pesawat dengan rea-lisasi waktu yang terjadi di Bandara.

Pada pelaksanaan pengangkutan penumpang, maskapai penerbangan membuat terlebih dahulu suatu bentuk perjanjian berupa tiket kepada penumpang. Pasal 1 angka 27 Undang-Undang Penerbangan memberikan pengertian tiket sebagai "dokumen berbentuk cetak, melalui proses elektronik atau bentuk lainnya, yang merupa-kan salah satu alat bukti adanya perjanjian angkutan udara antara penumpang dan pengangkut, dan hak penumpang untuk menggunakan pesawat udara atau diangkut dengan pesawat udara".

Suatu perjanjian dapat terlaksana dengan baik apabila para pihak telah memenuhi prestasinya masing-masing seperti apa yang telah diperjanjikan, baik oleh pi-hak pengangkut maupun pihak penumpang tanpa ada pihak yang dirugikan. Namun dalam pelaksanaannya, terkadang perjanjian tersebut tidak terlaksana sesuai dengan apa yang diharapkan, karena adanya wanprestasi yang dilakukan oleh salah satu pi-hak.

Berdasarkan hasil penelitian, maskapai penerbangan selalu memberikan gan-ti rugi dalam hal keterlambatan atau pembatalan penerbangan. Akan tetapi berdasar-kan informasi yang penulis dapatkan dari berbagai sumber, pelaksanaan tanggung jawab tersebut terhambat faktor pelayanan. Kurangnya pelayanan yang baik dari maskapai penerbangan dalam proses pemberian ganti rugi menyebabkan pelaksana-an tangggung jawab menjadi kurang efektif. Dengan adanya UndangUndang Pener-bangan dan Peraturan Menteri, diharapkan kerugian pada penumpang atas keterlam-batan penerbangan mendapat perhatian yang lebih baik dari pihak yang bertanggung jawab, dalam hal ini pihak maskapai penerbangan.

\section{Tanggung Jawab Maskapai Penerbangan Sebagai Penyedia Jasa Pe-nerbangan Kepada Konsumen Dalam Hal Terjadi Keterlambatan Pe-nerbangan}

Maskapai penerbangan atau badan usaha angkutan udara, dijelaskan pada Pa-sal 1 angka 5 PM 77 tahun 2011 yaitu "badan usaha angkutan udara adalah badan usaha milik negara, badan usaha milik daerah, atau badan hukum Indonesia berben-tuk perseroan terbatas, yang kegiatan utamanya mengoperasikan pesawat udara un-tuk digunakan mengangkut penumpang, kargo, dan/atau pos dengan 
memungut pembayaran". Sebagai badan usaha atau badan hukum, maskapai penerbangan dapat dimintai pertanggungjawaban apabila me-lakukan kesalahan.

Titik sentral dalam pembahasan mengenai tanggung jawab pengangkut adalah menyangkut prinsip tanggung jawab yang diterapkan. Ada beberapa bentuk pinsip tanggung jawab pengangkut yang dikenal dalam kegiatan pengangkutan, yang ma-sing-masing berbeda satu sama lainnya, baik itu cara pembebanan pembuktian, be-sarnya ganti kerugian, dan lain sebagainya. Penggunaan prinsip tanggung jawab pe-ngangkut sangat dipengaruhi oleh berbagai faktor.

Terdapat 3 (tiga) prinsip atau teori mengenai tanggung jawab pengangkut da-lam Hukum Udara Internasional, yaitu (E. Saefullah, 2008: 68):

a. Prinsip tanggung jawab atas adanya unsur kesalahan (liability based on fault),

b. Prinsip tanggung jawab praduga bersalah (presumption of liability), dan

c. Prinsip tanggung jawab mutlak (strict liability).

Pasal 1 ayat 30 PM 77 Tahun 2011 (sama dengan Pasal 1 angka 22 UndangUndang Penerbangan) menyebutkan bahwa "tanggung jawab pengangkut adalah kewajiban perusahaan angkutan udara untuk mengganti kerugian yang diserita oleh pe-numpang dan/atau pengirim barang serta pihak ketiga". Sedangkan dalam Pasal 2 di-jelaskan bahwa "pengangkut yang mengoperasikan pesawat udara wajib bertang-gung jawab atas kerugian terhadap:

a. Penumpang yang meninggal dunia, cacat tetap atau luka-luka,

b. Hilang atau rusaknya bagasi kabin,

c. Hilang, musnah atau rusaknya bagasi tercatat,

d. Hilang, musnah atau rusaknya kargo,

e. Keterlambatan angkutan udara, dan

f. Kerugian yang diderita oleh pihak ketiga.

Terkait kerugian yang ditimbulkan oleh maskapai penerbangan, maka pihak maskapai harus bertanggung jawab memberikan ganti kerugian kepada pihak penumpang yang dirugikan. Ganti kerugian sendiri dijelaskan pada Pasal 1 angka 18 PM 77 Tahun 2011 yaitu "ganti rugi adalah uang yang dibayarkan atau sebagai pengganti atas suatu kerugian". Ganti rugi erat kaitannya dengan tanggung jawab. Ganti kerugi-an juga diatur dalam Pasal 1243 KUHPerdata yaitu "ganti kerugian berupa penggan-tian biaya, rugi, atau bunga karena tak dipenuhinya suatu perikatan, barulah mulai diwajibkan, apabila si berutang, setelah dinyatakan lalai dalam memenuhi perikatan-nya, tetap melalaikannya, atau jika sesuatu yang harus diberikan atau dibuat dalam senggang waktu yang telah dilampaukannya".

Keterlambatan (delay) selama kurang lebih 2 jam mengharuskan maskapai penerbangan untuk memberikan ganti rugi sebagai bentuk tanggung jawab penyedia jasa penerbangan, sebagaimana diatur dalam Pasal 36 KM 25 Tahun 2008 yang me-ngatakan bahwa keterlambatan lebih dari 90 (sembilan puluh) menit sampai dengan 180 (seratus delapan puluh) menit, perusahaan angkutan udara niaga berjadwal wa-jib memberikan minuman, makanan ringan, makan siang atau malam dan memin-dahkan penumpang ke penerbangan berikutnya atau ke 
perusahaan angkutan udara niaga berjadwal lainnya, apabila diminta oleh penumpang.

Untuk keterlambatan selama 4 jam atau lebih mengharuskan maskapai mem-berikan ganti kerugian sebesar Rp. 300.000 (tiga ratus ribu rupiah) per penumpang atau memberikan ganti kerugian sebesar 50\% dari Rp. 300.000 apabila pengangkut menawarkan tempat tujuan lain yang terdekat dengan tujuan penerbangan akhir pe-numpang (re-routing) dan pengangkut wajib menyediakan tiket penerbangan lanju-tan atau menyediakan transportasi lain ke tempat tujuan apabila tidak ada moda tran-sportasi selain angkutan udara, sebagaimana diatur dalam Pasal 10 huruf a dan b PM 77 Tahun 2011.

Tanggung jawab penyedia jasa penerbangan dalam hal keterlambatan atau pembatalan jadwal penerbangan diatur di dalam Pasal 36 Peraturan Menteri Perhubungan No. KM 25 Tahun 2008 Tentang Penyelenggaraan Angkutan Udara dan Pasal 10, 11 dan 12 PM 77 Tahun 2011, yang menetapkan ketentuan serta besaran ganti kerugian akibat peristiwa keterlambatan maupun pembatalan penerbangan yang wajib diberikan oleh penyedia jasa kepada penumpang. Kedua aturan tersebut mene-rapkan prinsip presumption of liability yang mempunyai arti pengangkut secara oto-matis berkewajiban untuk mengganti kerugian kecuali pengangkut dapat membuk-tikan bahwa ia tidak bersalah atau beban pembuktian terbalik (Sri Syawali, 2000: 95).

Akan tetapi tanggung jawab kebanyakan maskapai penerbangan hanya sebatas memberikan ganti rugi berupa minuman dan makanan ringan serta menawarkan refund tiket, dan tidak mau melayani proses pengalihan penerbangan ke perusahaan penerbangan lainnya. Hal tersebut tentu melanggar Pasal 36 KM 25 Tahun 2008, yang menyatakan bahwa penyedia jasa penerbangan bertanggung jawab untuk membantu memindahkan penumpang ke perusahaan angkutan udara niaga berjadwal lainnya, apabila diminta oleh penumpang.

Seharusnya pemerintah memberikan sanksi kepada pihak maskapai penerba-ngan yang tidak menjalankan ketentuan yang telah ada. Jika pihak pengangkut tidak melaksanakan ganti kerugian atas sebuah keterlambatan angkutan udara dikarena-kan kesalahannya dan tidak termasuk dalam faktor pengecualian, maka pihak pe-ngangkut angkutan udara dapat dikenakan sanksi administratif berupa pembekuan izin atau bahkan sampai pencabutan izin operasi udara seperti yang tertera di dalam Pasal 26 PM 77 Tahun 2011. Sejauh ini beberapa maskapai angkutan udara yang ber-operasi, tidak melaksanakan pemberian ganti kerugian yang didasarkan pada per-aturan perundang-undangan ini dalam hal keterlambatan tersebut dikarenakan ke-salahan pihak pengangkut.

Menurut penulis, peristiwa keterlambatan (delay) penerbangan dalam kegiatan operasi angkutan udara adalah suatu hal yang tidak dapat diduga atau disangka kejadiannya, terlepas ada tidaknya kelalaian maupun kesalahan dari pihak yang terlibat di dalamnya, hal tersebut dapat terjadi kapanpun dan tidak ada yang mengingin-kan peristiwa ini terjadi. Karena selain merugikan para penumpang baik 
dari segi materiil maupun immateriil, pengangkut sebagai penyedia jasa angkutan juga dirugi-kan nama baiknya atas kejadian tersebut.

Selain tanggapan di atas, penulis juga menemukan beberapa kelemahan di dalam PM 77 tahun 2011, antara lain mengenai asuransi penumpang dan penggantian ganti kerugian sebesar Rp. 300.000. Bila dicermati dengan teliti, perusahaan pener-bangan membebankan premi asuransi dalam harga tiket yang harus dibayar oleh konsumen. Dengan demikian, perusahaan penerbangan berada pada pihak yang di-untungkan. Salah satu jenis ganti kerugian yang harus dibayar oleh maskapai pener-bangan apabila flight delayed lebih dari 4 jam sebesar Rp. 300.000. Pertanyaannya, apakah cukup adil menghargai waktu penumpang yang telah terbuang lebih dari 4 jam dengan Rp. 300.000? Pada PM 77 tahun 2011 tidak berlaku kelipatan waktu ke-terlambatan, sehingga terlambat 4 jam, 5 jam, dan seterusnya tetap hanya diberikan Rp.300.000,00. PM 77 tahun 2011 ini mendapat respon keras terhadap penerbitan-nya oleh INACA karena dinilai tidak berpihak kepada penumpang. Bahkan penulis juga seringkali menemukan pihak maskapai penerbangan menutupi kelemahannya dalam hal penyiapan pesawat udara beserta awaknya dengan alasan cuaca buruk (bad weather) atau departure slot time yang padat.

\section{Bentuk Perlindungan Hukum Terhadap Penumpang Sebagai Konsu- men Yang Dirugikan Akibat Keterlambatan Penerbangan}

Adanya keterlambatan penerbangan bagi penumpang tentunya akan menimbulkan kerugian terutama sekali perasaan jenuh menunggu, tertundanya aktifitasaktifitas yang semestinya dapat dilakukan bahkan akan kehilangan kesempatankesempatan, artinya terjadinya suatu keterlambatan penerbangan akan menimbulkan kerugian bagi penumpang,

Untuk mengatasi persaingan yang dapat menurunkan kualitas pelayanan dalam penerbangan maka diperlukan adanya suatu prinsip tanggung jawab yang sesuai untuk badan usaha angkutan udara niaga sebagai pelaku usaha khususnya dalam hal terjadi keterlambatan angkutan udara sehingga tercipta kepastian hukum yang me-menuhi rasa keadilan. Ketentuan yang dimaksud yaitu ketentuan yang mengatur ten-tang prinsip tanggung jawab angkutan udara.

Perlindungan hukum bagi penumpang angkutan udara adalah suatu masalah yang besar, dengan persaingan global yang terus berkembang. Perlindungan hukum sangat dibutuhkan dalam persaingan penerbangan global serta layanan yang menem-patkan penumpang angkutan udara dalam posisi tawar yang lemah. Perlindungan hu-kum bagi penumpang angkutan udara sebagaimana dimaksud adalah dalam bentuk perlindungan hukum yang diberikan oleh negara. Perlindungan hukum adalah perlin-dungan yang diberikan kepada subjek hukum, baik yang bersifat preventif (pencega-han) maupun represif (pemaksaan), baik secara tertulis maupun tidak tertulis untuk menegakkan peraturan hukum. Karena itu seluruh hubungan hukum harus mendapat perlindungan dari hukum. 
Penumpang pesawat udara berhak mendapat perlindungan hukum atas kerugian yang disebabkan keterlambatan, karena tanggung jawab pengangkut telah diatur secara khusus, maka tuntutan ganti rugi yang diajukan oleh penumpang mengacu kepada ketentuan hukum penerbangan nasional dan konvensi internasional tentang penerbangan yang telah diratifikasi. Namun, perlindungan hukum tersebut belum memberikan perlindungan hukum yang maksimal dan komprehensif terhadap hak-hak penumpang.

Menurut Undang-Undang Penerbangan dan PM 77 Tahun 2011, perlindungan hukum dapat dibuktikan dengan tiket penumpang. Tiket penumpang ini sebagai bukti adanya perjanjian antara pengangkut dan penumpang sehingga jika terjadi pelang-garan, dalam hal ini keterlambatan penerbangan, maka pengangkut wajib untuk mengganti rugi. Namun untuk melindungi penumpang yang dirugikan, dalam Un-dang-Undang Penerbangan dan PM 77 Tahun 2011, penumpang berhak untuk mela-kukan upaya hukum jika ternyata maskapai penerbangan tidak mengganti rugi. Kare-na masih belum terlihat jelas tentang sanksi apa yang akan diberikan apabila maska-pai penerbangan mengalami keterlambatan.

Hubungan hukum antara penumpang dengan pengangkut yang di lakukan melalui perjanjian masuk dalam bidang hukum perdata (privat), sehingga pada hake-katnya hubungan hukum yang terjadi antara penumpang dengan pengangkut (peru-sahaan penerbangan) bersifat individu dengan individu, di mana pemerintah seha-rusnya tidak terlibat, sesuai dengan asas kebebasan berkontrak yang dianut dalam hukum privat, maka seharusnya pemerintah tidak boleh turut campur tangan ter-hadap hubungan antara penumpang dengan pengangkut yang telah bersepakat. Akan tetapi pada perkembangannya, pengangkut sering kali menyalahgunakan kebebasan berkontrak yang akhirnya menimbulkan kerugian kepada penumpang atau pengguna jasa penerbangan.

Kewajiban pengangkut adalah sebagai konsekuensi kewajiban kontraktual (strict contractual duty) yaitu mengangkut penumpang dan mengirim barang sampai di tempat tujuan dengan selamat. Jadi, kewajiban pengangkut adalah untuk mencapai suatu hasil (obli-gation de resultant), bukan hanya sekedar untuk menyelenggarakan pengangkutan (obligetion de movens). Namun pada saat sekarang, perusahaan pener-bangan pada umumnya merupakan perusahaan besar dengan modal berjumlah mul-ti-milyar rupiah dan didukung dengan sistem asuransi -yang mendistribusikan resiko kepada berbagai pihak- sehingga posisi ekonomi perusahaan penerbangan sangat jauh lebih kuat dibanding posisi para pengguna jasa angkutan udara secara individu-al. Demikian juga di bidang teknologi, dunia penerbangan merupakan salah satu bi-dang yang menggunakan teknologi sangat canggih, sehingga tingkat keselamatan pe-nerbangan dewasa ini sudah jauh lebih baik dibanding pada waktu Ordonansi (atau Konvensi Warsawa dibuat). Ditambah pula dengan terjadinya perubahan sistem nilai dalam masyarakat sendiri yang sudah jauh berbeda dari 50 - 60 tahun yang lalu me-nyebabkan bahwa falsafah, dasar pertimbangan atau standar yang digunakan pada waktu pembuatan Ordonansi (atau Konvensi Warsawa) dipertanyakan kembali. Oleh karena itu, adalah 
wajar apabila Ordonansi 1939 tersebut dipandang sudah tidak me-madai lagi dan karenanya perlu diadakan pembaruan sesuai dengan perkembangan masyarakat.

Dengan demikian, jika penumpang pengangkutan udara dirugikan oleh maskapai penerbangan, maka ia dapat menuntut haknya untuk memperoleh ganti rugi. Mandat yang diamanatkan oleh Undang-Undang kepada para penyelenggara negara adalah melindungi hak-hak warganya, antara lain hak untuk memperoleh kemudahan mengakses transportasi serta hak untuk dijamin keselamatannya selama mengguna-kan jasa transportasi termasuk hak untuk mendapat ganti rugi.

\section{KESIMPULAN DAN SARAN}

\section{KESIMPULAN}

a. Bentuk tanggung jawab maskapai penerbangan terhadap penumpang atas keterlambatan penerbangan menerapkan konsep tanggung jawab hukum praduga bersalah (presumption of liability). Pemberian kompensasi yang wajib diberikan oleh maskapai penerbangan terhadap penumpang atas keterlambatan penerbangan beragam tergantung dari lamanya keterlamba-tan yang terjadi. Ada yang hanya diberikan minuman ringan, makanan dan minuman, hingga dapat dialihkan ke penerbangan berikutnya atau mengem-balikan seluruh biaya tiket. Mengenai pemberian ganti rugi sebesar Rp. 300.000, - (tiga ratus ribu rupiah) per penumpang tergantung kebijakan yang telah ditentukan oleh maskapai penerbangan yang bersangkutan.

b. Perlindungan hukum terhadap penumpang sebagai konsumen yang dirugikan akibat keterlambatan penerbangan menurut Undang-Undang Penerbangan dan PM 77 Tahun 2011 dapat dibuktikan dengan tiket penumpang. Tiket penumpang ini sebagai bukti adanya perjanjian antara pengangkut dan penumpang sehingga jika terjadi pelanggaran dalam hal ini keterlamba-tan penerbangan maka pengangkut wajib untuk mengganti rugi. Namun un-tuk melindungi penumpang yang dirugikan, dalam Undang-Undang Pener-bangan dan PM 77 Tahun 2011, penumpang berhak untuk melakukan upaya hukum jika ternyata maskapai penerbangan tidak mengganti rugi.

\section{SARAN}

a. Pemerintah dalam hal ini Direktorat Jenderal Perhubungan Udara sebagai pembina yang mengatur, mengendalikan dan mengawasi pengangkutan udara harus memberikan ketentuan tentang sanksi yang jelas dan tegas ter-hadap maskapai penerbangan jika tidak memberikan kompensasi atau ganti rugi kepada penum-pang yang mengalami keterlambatan penerbangan.

b. Kepada maskapai penerbangan di Indonesia agar lebih memperhatikan dan mengutamakan penumpang sebagai pengguna jasa penerbangan yang 
digu-nakan sebagai bentuk komitmen dan melaksanakan tanggung jawabnya dengan baik sebagai penyelenggara apabila terjadi hal-hal yang menjadi tanggung jawabnya seperti mengalami keterlambatan atau pembatalan penerbangan seperti yang telah diatur dalam Undang-Undang Penerbangan dan PM 77 Tahun 2011.

\section{DAFTAR PUSTAKA}

\section{BUKU DAN JURNAL}

Abdul Majid, Suharto Abdul Majid dan Probo Warpani, Eko (2009). Ground Handling Manajemen Pelayanan Darat Perusahaan Penerbangan. Jakarta: Raja Grafindo Persada.

Martono, K (2009). Hukum Penerbangan Berdasarkan UURI No.1 Tahun 2009. Bandung: Mandar Maju.

Nasution, M. N. (2007). Manajemen Transportasi. Bogor: Ghalia Indonesia.

Samsul, Inosentius Samsul (2003). Prinsip Tanggung Jawab Mutlak Dalam Hukum Perlindungan Konsumen. Jakarta: UI Press.

Setiani, Baiq (2015). Tanggung Jawab Pengangkut Udara Terhadap kerugian Yang Disebabkan Keterlambatan Berdasarkan Permenhub No. PM 77 Tahun 2011. Disertasi.

Shidarta (2004). Hukum Perlindungan Konsumen Indonesia. Jakarta: Grashindo. Syawali, Sri (2000). Hukum Perlindungan Konsumen. Bandung: Mandar Maju.

Wiradipradja, E. Saefullah (1989). Tanggung Jawab Pengangkut Dalam Hukum Pengangkutan Udara Internasional dan Nasional. Yogyakarta: Liberty. (2008). Hukum Transportasi Udara: Dari Warsawa 1929 Ke Montreal 1999. Bandung: Kiblat Buku Utama.

Yahanna, Annalisa et al. (2009). Passenger Rights and Liability of Commercial Air carrier in the Aviation Industry in Indonesia: Analysis of Law No. 1 Year 2009 about Aviation. Inaugural International Workshop and Seminar. Oriental Crystal Hotel, Kajang, Malaysia, 18-19 November 2009.

\section{PERATURAN PERUNDANG-UNDANGAN}

Keputusan Menteri Perhubungan Nomor 25 Tahun 2008 tentang Penyelenggaraan Angkutan Udara.

Kitab Undang-Undang Hukum Perdata

Peraturan Menteri Perhubungan Nomor 77 Tahun 2011 tentang Tanggung Jawab Pengangkut Angkutan Udara. 
Undang-Undang Nomor 1 Tahun 2009 tentang Penerbangan (Lembaran Negara RI Tahun 2009 Nomor 1, Tambahan Lembaran Negara RI Nomor 4956).

Undang-Undang Nomor 8 Tahun 1999 tentang Perlindungan Konsumen (Lembaran Negara RI Tahun 1999 Nomor 8, Tambahan Lembaran Negara RI Nomor 3821). 